\title{
Civic Rivalry and the Boundaries of Civic Identity in the French Wars of Religion: Châlons-sur-Marne and the Towns of Champagne ${ }^{1}$
}

MARK KONNERT

Summary: An examination of the policies and actions of the city council of the Champagne town of Châlons-sur-Marne during the French Wars of Religion qualifies the view that the wars spelled the end of the bonne ville. In particular, this article examines Châlons' rivalries with the other towns of the region. The civil wars of the Catholic League in the late 1580s and early 1590s provided the opportunity to gain by military means what had previously been sought by bureaucratic. Yet at the same time that the city councillors were pursuing the traditional agenda of the bonne ville, they were also illustrating the dynamic of its demise, for the prizes over which these rivalries were fought were royal institutions. They were playing an old game for new stakes.

A ccording to Bernard Chevalier, the towns of fifteenth- and sixteenthA century France, the bonnes villes, acted as semi-autonomous entities, which were distinct in kind from both the medieval cities which preceded them and the cities of the ancien régime which came after them in terms of administration, economic function, and culture. The kings of the era, far from seeking to restrict the independence of the bonnes villes, actually governed through them. In short, this was a golden age of urban culture and autonomy, one in which civic elites were valued partners in the government of the kingdom. But, according to Chevalier, the Wars of Religion were the death knell of the bonne ville. The civic identity of the bonne ville, he states, was 
ruptured by religious division. ${ }^{2}$ Moreover, faced with a central government steadily increasing in size and power, civic elites exchanged their civic roles and identities for positions with the royal government. ${ }^{3}$ Henceforth, their primary identification would be not with the city which they governed, but rather with burgeoning royal venal bureaucracy. Together, religious division and the "treason of the bourgeois" meant the death of the bonne ville, both processes reaching the point of no return in the late sixteenth century. Henceforth, an absolutist royal government would have the upper hand, ultimately emasculating urban autonomy altogether. ${ }^{4}$

Chevalier also states that attachment to, and the desire to reaffirm the values of the bonne ville played an important role in the attraction of most Catholic cities to the Catholic League after the tumultuous events of 1588 and 1589. ${ }^{5}$ Indeed, despite their disagreement over the goals and nature of the Catholic League, both Élie Barnavi and Robert Descimon agree that towns joined the League at least partly as a means of preserving or recovering lost or threatened autonomy. Descimon, in particular, has argued that the Sixteen in Paris were motivated by a desire to preserve the urban communal values of the Middle Ages. He finds a number of congruencies between these values and the ideology of the Sixteen. ${ }^{6}$ Élie Barnavi, with a very different view of the Sixteen's ideology, has nevertheless found a similar tendency for other French cities: "almost everywhere, indeed, the municipalities used the League to set themselves up as more or less autonomous entities."7

Clearly, however, this was a tendency which applied not only to the towns of the Catholic League, but to others as well, most notably to the Huguenot urban republics of the South and West. Indeed, the disorder and chaos of the period must have forced such autonomy on many towns whether they wanted it or not, as they were left on their own to ensure their security and integrity. It is perhaps not too much to say that the Wars of Religion provided the environment for a revival of the "state of the bonnes villes," as described by Bernard Chevalier for the fourteenth and fifteenth centuries. ${ }^{8}$ In short, the attempt to recover lost or threatened civic autonomy operated regardless of religious or politicial affiliation of the town in question.

But such autonomy is expressed only in actions. In theory alone, it is meaningless. Such towns are only autonomous if they are able to act autonomously. What did the governments of these newly "liberated" towns attempt to do? What were their agendas? To what did they devote their attention and resources? This article will focus on the city council of one town, the Champenois city of Châlons-sur-Marne, and on one aspect of their wartime 
autonomy: rivalry with the other towns of the region. Although, as we shall see, there was a certain amount of hostility toward Paris and the other major Champenois cities of Reims and Troyes, a special degree of hostility was reserved for the newly constructed town of Vitry-le-François, on the bank of the River Marne, about 30 kilometres upstream from Châlons. Châlons provides an especially interesting case study because it was a royalist Catholic town; therefore, a much clearer picture emerges of purely civic and local concerns, uncomplicated by the agendas of religious parties, whether the Huguenots or the Catholic League. Furthermore, the actions of the city councillors of Châlons, in conducting their rivalry with the other cities of the province, reveal both a devotion to the ideals of the bonne ville and the reality of the "treason of the bourgeois." Analysis of their actions takes us to the very heart of conflicting identities in sixteenth-century France.

\section{II}

In reading the minutes or livres des conclusions of the city council of Châlons-sur-Marne during the Wars of Religion, it is impossible to avoid the conclusion that the city councillors were overwhelmingly concerned with purely local issues. One finds long discussions, often stretching over weeks, months or even years, concerning fiscal issues, the repair and maintenance of the city's fortifications, care of the poor and plague-stricken, and relations with the bishop and Cathedral chapter. In general, the national events threatening to tear France apart find echoes in the city council only when they impinge directly on Châlons, when, that is, they have become local issues as well.

One of the concerns which recurs repeatedly throughout the minutes is a concern with the city's place and relative weight within the province of Champagne, reflecting a typical early modern preoccupation with rank and precedence. This concern has been extensively studied in the context of royal entries, civic processions, and great events such as the opening of the EstatesGeneral, and sessions of the Parlement. It is also something which was everpresent in the minds of the councillors of Châlons as they attempted to gain for their city the recognition and rank which they believed was its due. Thus, in 1561 when the bailli of Vermandois ordered the inhabitants of Châlons to send their representatives to Laon in preparation for the impending Estates-General, the council protested in strong terms that "Laon is not the capital city of Champagne." This concern of the councillors predated the wars, and continued throughout the period. In the context of this article, however, we see that 
the Wars of Religion changed the tactics and battleground, but that the basic concerns and rivalries persisted throughout the wars, and even influenced the course of events.

This rivalry may have even been more pronounced in Champagne than elsewhere in France because the province lacked a dominating metropolis such as Paris or Lyon. The functions that in other provinces were combined in one city were in Champagne divided among three: Reims, the seat of the Archbishop and the ecclesiastical capital of the province; Troyes, the leading industrial centre of the province; and Châlons, in many ways the administrative capital of Champagne. ${ }^{10}$

These three major cities of the province, however, lived together for the most part in an atmosphere of peaceful co-existence, at least until after 1588 when Reims and Troyes adhered to Catholic League while Châlons remained loyal, first to Henry III and then to Henry IV. Only when the situation in Champagne degenerated into open warfare did hostilities between Reims and Troyes and Châlons emerge into the open, with Reims as the primary stronghold of the League and Châlons of the royalists.

Despite this rivalry, the councils of the rival cities were perfectly capable of cooperating and coordinating their actions when matters of mutual interest were at stake. In 1559, when the king "requested" a "loan" of 50,000 livres from the cities of Champagne, the council wrote to the councils of Troyes and Reims in order to coordinate their strategy in remonstrating against the loan. In 1576, Châlons, Reims, and Troyes submitted joint remonstrances at court regarding the amount of the taille. ${ }^{11}$ Even in the midst of the civil war in the 1590s, royalist Châlons and Leaguer Reims signed a truce which permitted local workers to reap the harvest in peace. ${ }^{12}$ In short, the relationship between the three major cities of the province would best be characterized as one of mutual toleration, peaceful co-existence, and yet of underlying rivalry and suspicion. The three cities were capable of co-operating or fighting, depending on the issue at stake and the calculations and ambitions of those who governed them.

It has been argued, as mentioned above, that one of the Catholic League's major attractions to many towns was the opportunity to recover the autonomy of which a steadily centralizing monarchy had deprived them. Yet, as Élie Barnavi points out, having joined the League in order to escape the power of the royal government, many towns now found themselves subjected to the preeminence of a Paris dominated by the Sixteen. ${ }^{13}$ Even so, many towns preferred the tutelage of a distant and fractious Paris to that of an omnipresent royal 
bureaucracy. Châlons, however, was close enough to Paris (150 kilometres due east) that exchanging royal control for that of the Sixteen was no great bargain, all the more so since the agenda of the League was directly contrary to that of the city council on many issues. ${ }^{14}$ The leaders of Paris certainly did nothing to assuage the suspicions of the Châlonnais council.

Following the coup of the Sixteen in May 1588 in the Day of Barricades, and opening of the breach between the Parisian Leaguers and Henry III, the échevins of Paris attempted to enlist the other cities of France in the Catholic League. Like other cities, Châlons was pressed to swear an oath of allegiance to the newly-formed Conseil-Général de la Sainte Union, which the councillors were clearly reluctant to do. As indicated above, this refusal may be attributed to two different but related causes: opposition to the programme of the League in and of itself; and a desire not to be dominated by Paris. Thus, on June 7, the Châlonnais councillors received a letter from Paris soliciting Châlons' adherence to the Sainte Union:

Since the misfortunes proceeding from the disunity of the French are known to everyone, and ... as the root of them comes from the heretics, who by ruses and artifices wish to render the Catholic party so weak by its disunity that they may encompass our total ruin, and by the fog and obscurity of a miserable government, those who have abused the goodness of the king ... wish ... to grow fat on the substance of the people; we, who by divine grace, have up to now escaped the yoke of their tyranny ... have sent a humble request to His Majesty, and also advised of the need to communicate to all other cities, notably your own ... to request and pray you to immediately join your request to ours... The king will be more faithfully served and the people more assured and otherwise relieved. . . For this reason, we beg of you to continue the good beginning already established, and that this settlement which we request ... be confirmed by our mutual oath and promise, under one God, one faith, one king, and one law ... that by frequent conferences we may consider the expedient remedies for the restoration of a distressed state. $^{15}$

The Châlonnais council responded with delaying tactics, requesting the text of the petition and oath before agreeing. ${ }^{16}$ Indeed, the city council of Châlons only agreed to swear the oath after the king himself had given in to the League in Edict of Union in July.

At the same time that Châlons was resisting concerted pressure to join the League, the city was being showered with honours by Henry III. The king recognized Châlons as the "principal city of Champagne," an obvious slight to 
Reims and Troyes and a feather in Châlons' cap, and transferred to Châlons a portion of the Parlement of Paris, the cour de monnaies (monetary court) of Troyes, and the grenier à sel (royal salt warehouse) and siège présidial (intermediate court) of Vitry-le-François. ${ }^{17}$ All the while, Henry praised their fidelity and steadfastness: "We have heard ... of the good work continued by your good comportment, not only to conserve yourselves in our obedience, as God and reason command you, but also to serve as an example, to show the way to and encourage the other cities of my province of Champagne." 18

Following the murder of the Guises at Blois in December, the council acted swiftly and decisively to repudiate the League, expelling the baron de Rosne, Guise's lieutenant-général, and subsequently refusing to allow the entry of Bishop Cosme Clausse, an ardent Leaguer. Over the next several months, relations between Châlons and Leaguer towns, specifically with Reims and Paris, were deteriorating further. On February 19, the council arrested a Rémois merchant. ${ }^{19}$ More critical were relations with Paris and a hostage war between the two cities. Early in February, the échevins of Paris wrote to Châlons to ask for the release of two merchants held there along with their merchandise. These merchants, Nicolas Gombart and Fiacre Rolland, had apparently been arrested in retaliation for the Parisian authorities' refusal to give permission to leave Paris to two Châlonnais students at the Sorbonne, Michel Braux (son of city councillor Pierre Braux) and Louis Lallemant, and because the Parisians had detained boatloads of Lenten provisions bound for Châlons. Gombart and Rolland then wrote to Paris of their predicament, stating that the condition for their release was the release of the students and the cargo held in Paris. ${ }^{20}$

The Parisians wrote to the council that Châlons had not been singled out for discriminatory treatment. The students had not been detained because they were from Châlons. On the contrary, they were detained as protective measure, and in order to prevent the panic which might ensue from a general exodus of students. As to the seized merchandise, Châlons had been misinformed: the only merchandise seized was in retaliation for the alleged theft of 1,000 écus by someone from Châlons. This affair, therefore, had nothing to do with the League or the war. The letter concludes with a veiled threat: if this matter is not resolved amicably, Châlons stands to lose more than Paris. ${ }^{21}$ The Châlonnais reply is curt:

We have obtained from Monseigneur de Dinteville [the royalist lieutenantgénéral of Champagne] word that, if you free the children of our city and permit the free transport of the seized merchandise, he will discharge those 
whom he arrested with their merchandise. . The union of which you write is nothing other than what we have already sworn in obedience to His Majesty and according to his edict, which is to live and die in the Catholic, Apostolic, and Roman religion. . . Having nothing else to negotiate [ie. Châlons' adherence to the League], there is no need to delegate anyone. ${ }^{22}$

Eventually, the cities worked out a complicated swap: Gombart, Rolland, and their goods for the Châlonnais students and goods held in Paris. This seems to have fallen through, however, for on March 20, we find the council in Châlons deciding to sell the wares of Gombart and Rolland in compensation for the goods seized in Paris and for "the students and other persons detained in the city of Paris." 23

At the same time, the city council of Châlons was being inundated by letters from various figures active in the League. ${ }^{24}$ For our purposes, one of the most interesting was a letter from the city council of Reims in June 1589, which attempted to play on their common bourgeois identity, contrasting their common interests as bourgeois with those of the "gens de guerre":

Messieurs, we write to you ... to ask as warmly as possible that you have pity on our common miseries, which benefit only the gens de guerre ... But since you are bourgeois and urban dwellers such as ourselves, we beg you only to see that, now that the mask is lifted, it is clear that the king of Navarre is your chef, and that if his cause wins (which God does not want), we will without difficulty fall into the same state as England. . . 25

This overture was rebuffed as decisively as all the others.

\section{III}

Although there was rivalry with Paris, Reims, and Troyes, it tended to lay somewhat below the surface and emerged completely only in the chaotic atmosphere of the late 1580 s and early 1590 s when each city was thrown back completely upon its own resources. The rivalry with the new city of Vitry-leFrançois was of an entirely different order, since Châlons was opposed to its very existence. Indeed, since the city's construction in the 1540 s, the councillors of Châlons had continually schemed against their new rival and neighbour. Indeed, it is probably not too much to say that opposition to and rivalry with Vitry were constant features of conciliar policy throughout the Wars of Religion. ${ }^{26}$ Built on Francis I's orders in the late 1540s (hence the name), it replaced the old city of Vitry-en-Perthois which had been destroyed by Charles $\mathrm{V}$ in 1544. Châlons was opposed in principle to the existence of Vitry-le- 
François, for Vitry detracted from the honneur of Châlons in every way. Built consciously as a place forte, it threatened to supersede Châlons as a military entrepôt. Situated 20 miles upstream from Châlons on the bank of the Marne, it threatened Châlons' commerce. Vitry, a particular object of royal affection and favour, quickly became the site of an élection (the lower fiscal jurisdiction - the higher was the généralité) and a grenier à sel, as well as a siège particulier (branch) of the bailliage of Vermandois. These were all institutions which Châlons possessed as well, and the jurisdictions of those bodies based in Vitry were carved out of areas which had previously belonged to Châlons. In addition, Vitry was granted a siège présidial, the intermediate court between the bailliage and the Parlement of Paris, an honour which the Châlonnais could only envy.

The instances of contention between the two cities are numerous. Châlons had been granted the right to collect a tax or octroi on grain passing through the city. In February 1560 (1559 o.s.), it was reported to the council at Vitry that merchants were refusing to pay it. ${ }^{27}$ In 1568 , the council sent Jacques de Morillon, the lieutenant du bailli de Vermandois to court with a memorandum of the city's concerns. Heading the list was the translation of the siège présidial from Vitry to Châlons. ${ }^{28}$ In May of 1577 , word reached the Châlonnais council that a grenier à sel had been established in Vitry. The council wrote regarding this matter, among several others, to its agent in Paris, Pierre Paulmier, described as secrétaire ordinaire de la Royne..$^{29}$ At the same time Châlons schemed to have the élection of Vitry suppressed, authorizing a loan of 10,000 livres from the leading citizens to accomplish this. In fact, within three days this war chest was over-subscribed, and Châlons headed into this bureaucratic battle with 18,000 livres at its disposal. ${ }^{30}$ This battle went on for the better part of a year, until in April 1578 the council learned of an edict to suppress both the élection and grenier à sel of Vitry, the execution of which, however was to be deferred. ${ }^{31}$ In May, the council received a letter from Paulmier in Paris, informing them that the execution of the edict required a further payment of 100 écus to a secrétaire Bodin. The council sent the procureur and greffier of the élection of Châlons to court to request the moderation of this fee and to obtain the enforcment of the edict..$^{32}$ Ultimately, Châlonnais ambitions were defeated, and, very likely in retaliation, the grenetier à sel in Vitry refused to pay an octroi on salt previously paid to the grenier in Châlons. The council appealed to the trésoriers-généraux of the généralité of Châlons, who ruled in their favour, apparently to little effect, since more than a year later the grenetier in Vitry was still refusing to pay. ${ }^{33}$ This apparently prompted the Châlonnais 
to attempt once more the suppression of both the élection and grenier of Vitry. Once again, the council actually received letters announcing the suppression of the élection, but it seems that the suppression was not effected, for five months later, the council appealed to the trésoriers-généraux an octroi on salt assessed by the élection of Vitry. ${ }^{34}$

By 1582, when Vitry's fortifications were nearing completion, the city council of Châlons sent a deputation to court to protest that "the fortification would be to the great prejudice and injury of all Champagne and especially this city of Châlons." 35 The petition was doomed to failure, and in retaliation for Vitry fortifying itself, Châlons took aim at Vitry's siège particulier of the bailliage of Vermandois and its siège présidial, raising up to 12,000 livres to obtain their suppression. ${ }^{36}$

The civil war which broke out following the murder of the Guises at the end of 1588 provided Châlons with the opportunity to seize what it had long coveted. The war in Champagne consisted primarily of endemic provincial skirmishing between the League forces based in Reims and Vitry under their commanders St-Paul and de Rosne and the royalists under Dinteville and Thomassin. ${ }^{37}$ Châlons played an important part, both as a supplier of material, and as an outpost of royalist forces. On several occasions the civic militia of Châlons, in conjunction with the garrison posted in the town, took part in localized campaigns, consisting mostly of taking or retaking villages and castles held by the enemy.

Of these skirmishes, the most important for our purposes occurred in May of 1590 when the Châlonnais mounted an attack on Vitry. On the night of May 7, the Châlonnais forces penetrated the citadel through a blockhouse and liberated a captive royalist commander, killing the Leaguer governor de Mutigny in the process. The Châlonnais council, acting with alacrity, seized the opportunity to achieve its ultimate objective: the elimination of Vitry altogether. In a petition to the king, the council observed:

Vitry, because of its importance, is a place to either hold or destroy. For the former, it would be necessary for you to order all the captains, gentilhommes, and other persons bearing arms to follow and obey whomever You Majesty finds it fitting to command the campaign, to oppose the rebels who are troubling and may trouble your subjects, and rain down upon them; and to assign four or five hundred cavalry for reinforcements. For the latter, your poor subjects, inhabitants of your city of Châlons represent to you the infinite discomfitures that they and all the countryside have suffered because of the conservation of the said citadel and fortifications. Your poor and 
humble subjects, inhabitants of the said Châlons, judge that the said place and fortress of Vitry is too harmful to them and their neighbors, and that, if the place were razed and returned to farmland [rendue champestre] as it was in the year 1545, all the neighboring country would dwell in security and liberty, as it did before. ${ }^{38}$

Unfortunately for Châlons, St-Paul, who had been laying siege to Vassy with 4,000 men, quickly returned to Vitry, retaking the city on May 12 , thereby rendering the question purely academic. ${ }^{39}$

\section{IV}

Much of the research on the urban experience during the Wars of Religion has focussed on divisions within the city: Protestant versus Catholic, artisan versus bourgeois, noble versus royal government. This is quite natural, given the conflicts and tensions of the times: these divisions were real and important. Nevertheless, having our attention focussed so largely on divisions within the city may have blinded us to the identities which bound the citizens together.

It is clear that in certain conditions civic identity was strong enough to overcome, or least neutralize, the religious divisions within the city. ${ }^{40}$ In the context of this paper, we have seen that a sense of and commitment to an ongoing civic agenda - the rivalry with Vitry and attempts to crush it - were strong enough to persist throughout the divisions and disorders which both precipitated the wars and followed in their wake. As we have seen, the councillors of Châlons used these disorders to achieve what had been longstanding objectives, although by different means. Previously, they had relied on petitions, decrees, agents, and lawsuits. In the context of the late 1580 s and early 1590 s, they adopted loyalty to the king and military actions as the means to their desired ends.

The tenacity of urban identity and loyalty in the neighbouring province of Picardy has been examined by Annette Finley-Crosswhite. Despite strong familial and economic ties, despite the pervasive patronage networks of Mayenne and Aumale, despite their common devotion to the ideals of the League and assent to the Conseil-Général, the towns of Picardy were ultimately unable to cooperate effectively. An attempt at creating a regional League urban alliance foundered on the rocks of civic particularism: "[i]n the end urban identity was much stronger than regional identity." And, one might add, urban identity was also able to neutralize devotion to a common religious and ideological agenda. ${ }^{41}$ If the cities of Picardy could not cooperate with one 
another despite everything going for this alliance, how much more should we expect civic rivalry when none of these favourable factors were present, as was the case in Champagne?

No one would suggest that Châlons remained loyal to Henry III and recognized Henry IV simply because Reims, Troyes, and especially Vitry were League towns. But it was a factor nevertheless, at the very least in a negative sense: their loyalty to Henry III had been well-rewarded. The political divisions of the time allowed the Châlonnais council to finally obtain what it had long sought: recognition as the principal city of Champagne, the suppression of Vitry's élection, grenier à sel, and siège particulier of the bailliage of Vermandois, and the transfer to Châlons of Vitry's siège présidial. The fact that Châlons and Vitry were now on opposite sides of an open military conflict also presented the possibility of the final elimination of Vitry as a rival, a goal apparently so nearly achieved in the spring of 1590 . Withdrawing their support of Henry III, or refusing to recognize Henry IV, besides whatever other reasons for which such a course was unpalatable, would have meant the loss of all that Châlons had gained.

In light of the above, we must re-evaluate Chevalier's rather straightforward picture of the bonne ville collapsing in the face of religious division and the "treason of the bourgeois." What we have seen in Châlons leads to a somewhat more complex conclusion. When we look at the personnel of the city council, we see that commitment to the civic agenda, of which the subjugation of Vitry was a part, was able to cut across institutional and occupational lines. The city councillors included not only the lieutenant of the bailli of Vermandois, but also the bailli of the bishop, the avocat and procureurdu roi, not to mention numerous élus, a receveur des aides, two trésoriers de France, and at least one receveur-général. Yet, on issues such as the rivalry with Vitry, no matter what their institutional ties, the city councillors apparently pursued their civic agenda first. Yet the very fact that so many of these men were also royal officers necessarily determined the ground on which these civic rivalries would be contested. This was the competition for plums from royal largesse. The city councillors of Châlons took aim at the cour de monnaies of Troyes, the siège présidial, the grenier à sel, the siège particulier, and the élection of Vitry. They were playing an old game, but for new stakes. Even in fighting the old rivalries of the bonnes villes, they demonstrated the "treason of the bourgeois." Though the loyalties may have been balanced, complementary, or perhaps even confused in their own minds, how long could it be until one prevailed over the other? 
The case of Châlons-sur-Marne and its rivalry with the cities of Champagne demonstrates yet again the reality of a multiplicity of ties and identifications. The vast majority of city councillors were Catholic, yet they chose to identify with the royalist rather than the Leaguer cause. They were also bourgeois (in the older and more restrictive sense of the term). Thus when confronted with disorderly soldiers, noble pretensions, or royal fiscal demands, they were able to make common cause with bourgeois of Reims and Troyes, despite their longstanding and mutual suspicion. They were also Châlonnais, and as such, pursued the traditional agenda of the town's elite. Yet they were also increasingly tied to and dependent upon the burgeoning royal venal bureaucracy, and this necessarily influenced their actions and policies. Which courses individuals and communities chose cannot be illuminated on the basis of grand themes and great movements, important though these may be. If we are to truly understand how communities and individuals made the decisions they did, we must come to terms with the reality of different and conflicting identifications and their interaction in the local political matrix.

University of Calgary

\section{Notes}

1. Bernard Chevalier, Les bonnes villes de France du XIVe au XVI siècle (Paris: AubierMontaigne, 1982), pp. 288, 302-308.

2. Ibid., pp. 129-149.

3. Ibid., pp. 106-112.

4. Ibid., p. 111.

5. Robert Descimon, Qui étaient les Seize? Mythes et réalités de la ligue parisienne (15851594) (Paris: Fédération des Sociétés Historiques et Archéologiques de Paris et de l'Île-deFrance, 1983), pp. 281, 295-296.

6. Élie Barnavi, "Centralisme ou fédéralisme? Les relations entre Paris et les villes à l'époque de la Ligue (1585-1594)," Revue Historique, 259 (1978), p. 336. On his views of the Sixteen's ideology, see Le parti de Dieu: étude sociale et politique des chefs de la Ligue parisienne, 1585-1594 (Brussels: Nauwelaerts, 1980). This idea has also been expressed by Fernand Braudel, who sees in the League "a return to an age of urban independence, the age of the city-state." (The Mediterranean and the Mediterranean World in the Age of Philip II, trans. Siân Reynolds [New York: Harper and Row, 1973], II, 1215). See also Peter M. Ascoli, "French Provincial Cities and the Catholic League," Occasional Papers of the American Society for Reformation Research, I (1977), 15-40, esp. pp. 21-27.

7. One is struck by the similarities between the conditions of the Wars of Religion and those of the Hundred Years' War, which produced the "state of bonnes villes," with the significant 
exception of religious division. Even so, in both cases, towns were left more on their own affairs, and whoever wished to dominate national politics had to gain the support of the towns. Chevalier attributes, as does Descimon, the attraction of the League for many cities to a link between its Catholic ideology and the characteristics of the bonne ville, a link at least called into question by the experience of Châlons, which both resisted the League and remained devoted to the ideals of the bonne ville.

8. Archives départementales de la Marne ( $A D M)$, E Suppt. 4785, fol. 43.

9. This parallels the developments noted by Ted Margadant at the time of the French Revolution, particularly the distinction between administrative centres and economic centres (Urban Rivalries in the French Revolution [Princeton: Princeton University Press, 1992], pp. 22-23, 82-83). Note especially the continued rivalry of the towns of Champagne during the administrative reorganization of the Revolutionary era (Margadant, pp. 32, 92). Amanda Eurich has detected a similar phenomenon in Béarn in the sixteenth century, where the administrative centre of Pau and the economic centre of Orthez vied for the newlyfounded Academy of Béarn ("Education, Civic Identity and the Creation of a Huguenot Elite: The Academy of Béarn, 1565-1579," paper presented at the Sixteenth-Century Studies Conference, St. Louis, Missouri, December, 1993. The author is grateful to Dr. Eurich for a copy of her paper).

10. $A D M$ E Suppt 4785 fol. $2 ; 4787$, fol. 83 .

11. On this truce, see M. Poinsignon, Histoire générale de la Champagne et de Brie (Paris, 1885 , 1898; rpt. Paris: Guénégaud, 1974), II, pp. 385-391; E. Henry, La réforme et la ligue en Champagne et à Reims (Saint-Nicolas, 1867), pp. 249-277; E. de Barthélémy, Histoire de la ville de Châlons-sur-Marne de ses origines à 1848 (Châlons-sur-Marne, 1883), pp. 314319; G. Hérelle, La Réforme et la Ligue en Champagne (Paris, 1888-1892), I, pp. 305-321, 325-353.

12. É. Barnavi, “Centralisation."

13. For example, the city council repeatedly protected native Huguenots from persecution at the hands of the outsiders, repeatedly attempted to resist the domination of the duc de Guise, and steadfastly opposed efforts to billet garrisons in the city. See. M. Konnert, "Urban Values Versus Religious Passion: Châlons-sur-Marne During the Wars of Religion," Sixteenth Century Journal, 20, 3 (1989), 387-405; “A Tolerant City Council? Châlons-sur-Marne During the Wars of religion," Proceedings of the Annual Meeting of the Western Society for French History, 16 (1989), 40-47.

14. "Puisque les malheurs procédans de la désunion des Françoys sont congneus à ung chacun, et que les plus clairvoyans jugent que, comme la racine en est extraicte des hérétiques, ... qui par ruses et artifices veulent rendre le party des catholiques si faible par leur désunion que avec le temps ilz puissent parvenir à nostre entière ruyne, et par le brouillart et obscurité d'ung si misérable gouvernement ceux qui ont abusé de la bonté du Roy se puissent, comme l'on voit, grandir de la substance de tout le peuple; nous, qui, de la grâce divine, avons eschappé jusques icy le dernier joug sde leur tirannie, ... avons envoyé nostre trèshumble requeste à Sa Majesté, avons aussi advisé estre besoing la communicquer à toutes les aultres villes, et notamment à la vostre ... vous prians et requérans trèsinstamment de joindre vostre requeste à la nostre. [. . .] Le Roy en sera plus fidellement servy et le peuple mieulx asseuré et aultrement solagé. .." (ADM E Suppt. 4789, fols. 27-28). 


\section{Ibid.}

16. Hérelle, I, pp. 198-200.

17. Ibid., pp. 176-177.

18. $A D M$ E Suppt. 4789 , fol. 62.

19. ADM E Suppt. 4789, fol. 63; Hérelle, I, pp. 177-186.

20. Hérelle, I, pp. 178-179.

21. "Messieurs, nous avons obtenu de Monseigneur de Dinteville, .. . que licenciantz par vous les enffans de nostre ville et permettant le transport libre de marchandises arrestées, qu'il renvoyra ceux qui sont icy arrestes. [... L L'union de laquelle nous escipvez n'est aultre que celle qu'avons juré soubz l'obeissance de Sa Majesté et suivant son édit, qui est de vivre et mourir en la relligion catholicque, apostolicque et romaine. N'ayant aultre chose à traicter avec vous, il n'est nécessaire de déléguer aucuns de nous avecq procuration" (Hérelle, I, p. $181)$.

22. "... pour la déliverance des escolliers et autres personnes dud. Chaalons qui sont detenuez en lad. ville de Paris" (ADM E Suppt. 4789, fol. 67).

23. Besides the échevins of Paris was solicited, and sometimes threatened, to join the League by the city councils of Troyes and Reims, the Duke of Lorraine, de Rosne and St-Paul (the two principal Leaguer commanders in Champagne), and Guise's widow, Catherine de Clèves (See Hérelle, I, pp. 168-171, 187-188, 221-224).

24. "Messieurs, nous avons pris subject de vous envoyer la présente ... pour vous supplier, aultant affectionnément qu'il nous est possible, que vous ayez pitié de nos misères communes, qui ne tournent qu'au proffict des gens de guerre... Mais, puisque vous etes bourgeois et habitants de ville, comme nous, nous vous pryons seullement de voir que, maintenant que le masque est découvert, il vous appert assez que le roy de Navarre est votre chef, et que, gaignant sa cause (que Dieu ne veuille), il n'y a difficulté quelconque que nous ne tombions en l'estat d'Angleterre" (Quoted in Henry, pp. 148-149).

25. On Vitry, see R. Crozet, "Une ville neuve du XVI' siècle: Vitry-le-François," La vie urbaine, 5 (1923), 291-309; "Le protestantisme et la ligue à Vitry-le-François et en Perthois," Revue historique, 156 (1927), 1-40.

26. $A D M$ E Suppt. 4785 , fols. 18, 22-23, 236.

27. $A D M$ E Suppt. 4786 , fol. 109.

28. $A D M$ E Suppt. 4787 , fols. $132,133$.

29. $A D M$ E Suppt. 4787, fols. $138,139$.

30. $A D M$ E Suppt. 4787 , fols. $147,148$.

31. ADM E Suppt. 4787, fol. 149.

32. ADM E Suppt. 4787, fols. 170-171, 174, 237.

33. $A D M$ E Suppt. 4787 , fol. 236. 
34. ADM E Suppt. 4788 , fol. 37.

35. $A D M$ E Suppt. 4788 , fols $39-40$.

36. Philippe de Thomassin was named by Dinteville to replace the expelled de Rosne as garrison commander and royal governor of Châlons on January 1, 1589. See $A D M$ E Suppt 4789 , fol. 42; Hérelle, I, pp. 158-159; G. Hérelle, ed. Mémoire des choses plus notables advenues en la province de Champagne (Reims, 1882), p. 162.

37. Hérelle, I, p. 243.

38. G. Hérelle, ed. Mémoire des choses plus notables advenues en la province de Champagne, 1585-98 (Trav. Ad. Reims, 68 1879), pp. 104-106; Henry, pp. 169-170.

39. M. Konnert, "Urban Values ...," and "A Tolerant City Council?." For a comparable situation in England, see Muriel McClendon, “'Against God's Word”: Government, Religion and the Crisis of Authority in Early Reformation Norwich," Sixteenth Century Journal, 25, 2 (1994), p. 361. For a related argument, see Henry Kamen, "Toleration and Dissent in Sixteenth-Century Spain: The Alternative Tradition," Sixteenth Century Journal, 19 (1988), 3-23.

40. Annette Finley-Crosswhite, "The Boundaries of regional Identity: Urban alliances in Picardy, 1588-1594," paper presented at the Sixteenth Century Studies Conference, St. Louis, Missouri, December 1993. The author is grateful to Dr. Finley-Crosswhite for a copy of her paper. See also her "Urban Identity and Transitional Politics: The Transformation of Political Allegiance Inside Amiens Before and After the City's 1594 Capitulation to Henry IV," Proceedings of the Annual Meeting of the Western Society for French History, 20 (1993), 53-61, esp. pp. 56-57. See also Ascoli, pp. 29, 36. 